American Journal of Economics and Business Administration 3 (2): 247-258, 2011

ISSN 1945-5488

(C) 2011 Science Publications

\title{
Regionalism in East Asia: The Role of North East Asian Nations
}

\author{
Fithra Faisal Hastiadi \\ Graduate School of Asia-Pacific Studies, \\ International Economics Laboratory, \\ Waseda University1-21-1 Nishi-Waseda, Shinjuku-Ku, Tokyo 169-0051, Tokyo
}

\begin{abstract}
Problem statement: For the past few years, regionalism has been progressing in East Asia with the likes of China, Japan and Korea (CJK) as the most prominent actors. Unfortunately, with the absence of trade arrangement amongst the CJK, the present regional trade scheme is not sufficient to reach sustainability. Thus, the study aims to give the solution to the problem. This study found the inefficient trade scheme through Engle-Granger Cointegration and Error Correction Mechanism. Two Stage Least Squares in a static panel fixed effect model were also employed to proof the spill-over effect. Conclusion/Recommendations: The study underlines the importance of triangular trade agreement for accelerating the phase of growth in CJK which eventually created a spillover effect to East Asia as a whole. Moreover, the study argued that the spillover effect would function as an impetus for creating region-wide FTA. Furthermore, the study also identified a number of economic and political factors that can support the formation of East Asian Regionalism.
\end{abstract}

Key words: Engle-granger cointegration, error correction mechanism, fixed effect, Error Correction Mechanism (ECM), Economic Partnership Agreements (EPAs), Regional Trade Agreements (RTAs), long run equilibrium, relative price level

\section{INTRODUCTION}

In this new millennium, regionalism has begun to emerge in East Asia. A more integrated region will only lead to an intense opportunity for trading activities (Toosi et al., 2009). Having said this, we have seen how East Asian Countries have been focusing on ways to expand intra regional trade that include: the establishment of Regional Trade Agreements (RTAs) in the form of Free Trade Agreements (FTAs) and Economic Partnership Agreements (EPAs). The trend towards regionalism has created a profound regional and indeed global significance (Charles and Lee, 2002). Japan, Korea and China are regarded as the key actors for such action in East Asia.

Being acknowledged as the economic front runners, Japan, China and Korea are assumed to have heavy responsibility for the economic welfare in the East Asian region. It is very obvious that East Asian regionalism cannot be put into practice without these countries' strong support. Unfortunately, the lack of institutional arrangements among these giant countries has stalled the overall welfare effect for the East Asian communities. The present driving force of the ChinaJapan-Korea (CJK) relationship is the market by which in some sense is not enough; it should be matched by regionalism. The main focus of the regionalism is to make these countries grow together so that it can spread positive externalities throughout the East Asian region. In the long run it is expected that CJK will lead regionalism in East Asia.

Japan, China and Korea economic relation: Tracing back the relations since the post war era, economic ties between Japan, Korea and China has evolved in somewhat gradual ways. The evolution of trade activities emerged from the likes of China, which has a substantial transformation of trade structures. In the early 90's, primary commodities accounted for more than one third of China's total export to Japan and Korea. In this new millennium, it is still top Chinese export to Japan and Korea, but it is persistently followed by the fast growth of machinery and transport (Chan and Kuo, 2005). From this point of view, trade within the north East Asian region is deemed to have substantial movement as a result from the shift of trade towards a more industrialized structure. The emergence of China as a regional manufacturing center is a dominant factor that contributes the trade shift. 


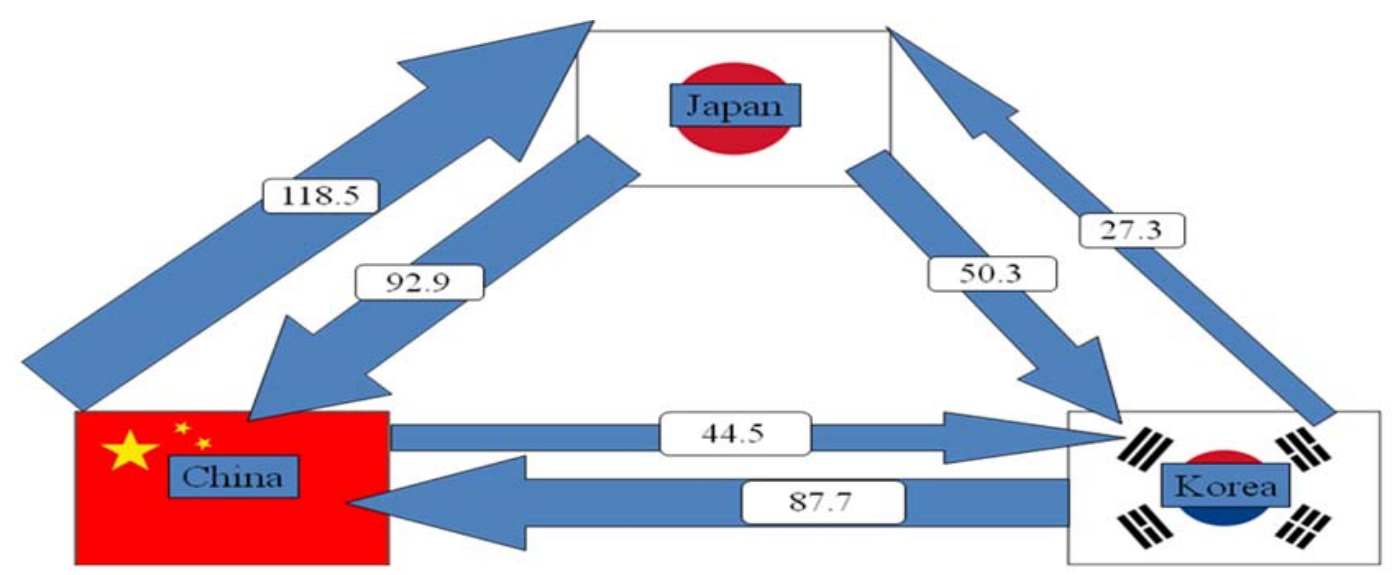

Fig.1: Trade among Japan, China and Korea (2006, \$billion) Source: Yorizumi, (2008)



Fig. 2: Investment among Japan, China and Korea (2005, \$billion) Source: Yorizumi (2008)

The overall picture of the trade amongst these countries is described in Fig. 1. It is clear that trade activity is very intense by which performs as the major contributing factor for economic growth in the region. The vast amount of trade has been very likely steered up by the amount of FDI flows among them with Japan as the sole leader of it (Fig. 2). In other words, the creation of economic transformation in China and Korea that geared up the trade was enchanted by Japan's role in making investment in those countries.

The remainder of the study is organized as follows. The second section studies the materials and methods The third section examines the result of the regressions. The last section presents conclusion and some concluding remarks.

\section{MATERIALS AND METHODS}

Measuring the short and the long run equilibrium of export to GDP: To some extent, trade is almost synonymous to a country's welfare. More specifically, some research pointed out export as an engine of economic growth. From this stand point, it is important to measure export sustainability to the economy, which in this case, export among the CJK become the main focus.

As already explained earlier, Japan, China and Korea are experiencing golden period in doing export among them. Economic welfare is the most no Table goal which links in this activity, but is it sufficient to boost the economy in the long run? A pure market driven activity without specific regional trade agreement might sometime create bias. It is clear that Japan, Korea and China are lacking of such agreement among them (Urata and Kiyota, 2003) as described in the Table 1.

To make an effective regionalism, Japan, China and Korea should support each other. Therefore, intra regional cooperation within the CJK must take place by which can create sustainable growth in East Asian 
Am. J. of Economics and Business Administration 3 (2): 247-258, 2011

Table 1: Japan, China and Korea FTAs/EPAs

\begin{tabular}{lll}
\hline Countries & Situation & Countries \\
\hline \multirow{2}{*}{ China } & Concluded & Chile, ASEAN, Hong Kong, Macao \\
& Under negotiations & NZ, Australia, Pakistan, Singapore, \\
& & GCC, SACU \\
& Under considerations & Iceland, India, Japan-Korea-China, \\
Korea & FTAAP, Switzerland \\
& Concluded & Chile, Singapore, EFTA, ASEAN, USA \\
& Under negotiations & India, Mexico, Canada, eu \\
& Concluded & FTAAP, China, Mercosur, NZ, South \\
Japan & Africa, Japan-China-Korea, Australia, GCC \\
& Under negotiations & Singapore, Mexico, Malaysia, Philippines, \\
& & Chile, Thailand, Brunei, Indonesia \\
Source: Japanese & India, Vietnam, Australia, Switzerland, \\
& Under considerations & Korea, GCC, ASEAN \\
\end{tabular}

To make an effective regionalism, Japan, China and Korea should support each other. Therefore, intra regional cooperation within the CJK must take place by which can create sustainable growth in East Asian region. The followings serve to prove export sustainability to economic growth, in the absence of trade arrangements, for the short and the long run. Error Correction and Engle-Granger Cointegration Mechanism test are then employed for this cause. This test employs time series quarterly data of GDP and for Japan, China and Korea ranging from 1985-2004. The data is taken from CEIC data base.

Defining the long run equilibrium: Engle granger cointegration test: Cointegration method is notably the best way to measure the long run equilibrium (Dritsakis and Gialetaki, 2005, Habibi and Rahim, 2009; Khosravi and Karimi, 2010; Engle and Granger, 1987). In doing Engle Granger Cointegration test, this study divides the export relationship in to three parts which are described in the following equations:

- China and Japan Export Relationship

$\mathrm{JPGDP}=\beta_{0}+\beta_{1}$ ExportCH$+\mathrm{u}_{\mathrm{t}}$

CHGDP $=\beta_{0}+\beta_{1}$ ExportJP $+u_{t}$

- $\quad$ Korea and Japan Export Relationship

$\mathrm{KRGDP}=\beta_{0}+\beta_{1}$ ExportJP $+\mathrm{u}_{\mathrm{t}}$

$\mathrm{JPGDP}=\beta_{0}+\beta_{1}$ ExportKR $+\mathrm{u}_{\mathrm{t}}$
- China and Korea Export Relationship

CHGDP $=\beta_{0}+\beta_{1}$ ExportKR $+u_{t}$

$\mathrm{KRGDP}=\beta_{0}+\beta_{1}$ ExportCH $+\mathrm{u}_{\mathrm{t}}$

In these equations, JPGDP, CHGDP and KRGDP are Japan's GDP, China's GDP and Korea's GDP respectively while Export JP, Export $\mathrm{CH}$ and Export $\mathrm{KR}$ are the variables of export destinations to Japan, China and Korea. It would be possible to cointegrate Export and GDP since the trend in export and GDP would offset to each other, creating a stationary residual. The residual is called a cointegration parameter. In the data, if we find that the initial regression of the residual (ut) gives stationarity it means that ut is stationary at order 0 (level) and it is notated as $\mathrm{I}(0)$. But if ut is stationer in first difference, the variables of Export and GDP will be cointegrated in the first difference which can be notated with I(1).

Defining the short run equilibrium: Error correction mechanism: We have already defined the long run relationship between Export and GDP. However, in order to make it objective, we should also define the short run. The technique to correct short-run disequilibrium to its long run long run equilibrium is called Error Correction Mechanism (ECM). The model of ECM is as follows:

$\Delta$ GDP CountryX $=\beta_{0}+\beta_{1} \Delta$

Export countryY $+\beta_{2} u_{t}+e_{t}$

$\mathrm{u}_{\mathrm{t}-1}$ Is a cointegrated error lag 1 , or could be noted mathematically as: 
$U_{t-1}=$ GDPCountryX $_{t-1} \beta_{0}-\beta_{1}$ Export Country $_{t-1}$

In this equation, $\triangle \mathrm{GDP}$ CountryX is the difference in GDP for Japan, Korea and China, while $\Delta$ ExportCountry $Y$ is the difference in export from country $\mathrm{X}$ to Country $\mathrm{Y}$. As for example, $\Delta$ GDP Japan $=\beta_{0}+\beta_{1} \Delta$ Export China $+\beta_{2} \mathrm{u}_{\mathrm{t}-1}+\mathrm{e}_{\mathrm{t}}$ applies

for the effect of Japan's export to China on Japan's GDP.

The openness in trade: Greater economic interdependence between Japan, China and Korea will act well as the base of creating regionalism. In this sense, triangular trade agreements that dismantle trade barriers will smooth the progress of improved trade flows among these countries by means of greater market access. But unfortunately, this supporting environment only operates as fact in a sheet. The process of regionalism in this area is proven to be difficult.

These countries may have aggressively reached other countries in making FTA's and EPA's but none of which have been progressing among them (Table 1). The reason of it will be a subject for another research, while this research tries to focus on the effect of such agreement to the economy. The lack of trade arrangements is being noted as the main factor that contributes intra regional trade ineffectiveness in north East Asia. This hypothesis will be proved in the followings.

Openness with customized RPL index: Export lead growth approach that has been done with the cointegration and ECM has actually provided the basis to measure openness of a country, but in some ways this alone is not enough. It only works for confirming the paradigm of trade as an engine of growth but it is not sufficient to measure a more robust pattern of openness. Therefore, we then may have to address Dollar (1992) Relative Price Level (RPL index).

This index is a measure of outward orientation of an economy which was explored by Summers and Heston (1988). Using the US as the benchmark country, the index of country i's Relative Price Level (RPL) is:

$\mathrm{RPL}_{\mathrm{i}}=100 \times \mathrm{P}_{\mathrm{i}} / \mathrm{P}_{\mathrm{us}} \times 1 / \mathrm{e}$

Where $\mathrm{e}$ is the exchange rate and $\mathrm{P}_{\mathrm{i}}$ is the consumption price index for country $\mathrm{i}$ and $\mathrm{P}_{\text {us }}$ is the consumption price index for US. Therefore, we can use the formula to measure inward- or outward-orientation of a trade policy. With using the same analogy, this study then customizes the RPL index into this formula:

$\mathrm{RPL}_{\mathrm{i}}=100 \times \mathrm{P}_{\mathrm{i}} / \mathrm{P}_{\mathrm{tp}} \times 1 / \mathrm{e}$

Where $\mathrm{P}_{\mathrm{tp}}$ is the consumption price index for the trading partner and $\mathrm{e}$ is the exchange rate (no. of units of domestic currency per unit of trading partner currency). The customized RPL is then become a powerful tool to analyze trade openness between the trading countries.

Error Correction Mechanism (ECM) of RPL index and GDP: As already explained, ECM provides the description of short run shock. In this particular case, we examine the openness vis a vis trade liberalization trend in north East Asia region. This test employs time series quarterly data of Exchange rate, CPI, Export for CJK ranging from 2001 to 2005 , the data is taken from CEIC data base. Below is the equation:

$\Delta$ GDP CountryX $=\beta_{0}+\beta_{1} \Delta$ RPL CountryY $+\beta_{2} u_{t-1}+e_{t}$

This equation mimics Eq. 7, but the previous dependent variable is substituted from export to RPL in order to suit the goal which is to measure the openness. $\triangle$ GDP CountryX is the difference in GDP from Japan, Korea and China, $\triangle \mathrm{RPL}$ CountryY is the difference in RPL from a country $X$ to Country $Y$. $\triangle$ RPL CountryY measures the openness of trade from of country $\mathrm{X}$ towards $\mathrm{Y}$.

The Spillover Effect from Japan-Korea-China Triangular Trade to ASEAN 4: As giants of Asia, the growth of Japan, Korea and China will most likely create positive effect to the neighboring countries. Regionally speaking, the growth of North East Asia will boost the East Asian growth as whole, in this sense we might want to exercise its effect to ASEAN countries. To simplify things, this study limits the effect to ASEAN4 since these countries have the same economic characteristics. This study employs static panel data model for this purpose. The panel data is analyzed annually from 1989-2007 which consist of ASEAN 4's Export, Import, Consumption, Investment, Government expenditure, GDP and GDP of Japan, China, Korea. The data is taken from WDI online database. The following provides the analysis. 
Examining the spillover effect through panel data model: A static panel data model can be specified as follows:

$Y_{i t}=X_{i t} \beta+\lambda_{t}+\eta_{i}+\varepsilon_{i t} t=1, \ldots, T i=1, \ldots, N$

Where: $\lambda_{t}$ and $\eta_{i}$ are time and individual specific effects respectively, $x$ it is a vector of the explanatory variables, (i) is the time component of the panel, (N) is the cross-section dimension (or the number of cross-section observations) and $\mathrm{N} x \mathrm{~T}$ is the total number of observations. The idea is to run the models in order to have a consistent estimator for the $\beta$ coefficients and the model (fixed or random) choice depends on the hypothesis assumed for the relationship between the error-term (cit) and the regressors ( $\mathrm{x}$ it ). The static panel data analysis developed in the study is based on two basic panel models, the Fixed (FE) and the Random (RE) effect models. Since the time periods (1989-2007) exceed the individual observations (Indonesia, Malaysia, Thailand, Philippines) therefore FE is considered as the most appropriate method (Nachrowi, 2006). The model is described as follows:

$$
\begin{aligned}
& \mathrm{Y}_{\mathrm{it}}=\alpha+\beta \mathrm{X}_{\mathrm{it}}+\gamma_{1} \mathrm{~W}_{1 \mathrm{t}}+\gamma_{2} \mathrm{~W}_{2 \mathrm{t}}+\gamma_{3} \mathrm{~W}_{3 \mathrm{t}}+\ldots \ldots+ \\
& \gamma_{\mathrm{N}} \mathrm{W}_{\mathrm{N}}+\delta_{1} \mathrm{Z}_{\mathrm{i} 1}+\delta_{2} \mathrm{Z}_{\mathrm{i} 2}+\delta_{3} \mathrm{Z}_{\mathrm{i} 3}+\ldots . \delta_{\mathrm{t}} \mathrm{Z}_{\mathrm{iT}}+\mathrm{e}_{\mathrm{it}}
\end{aligned}
$$

Where:

$\mathrm{Y}_{\mathrm{it}} \quad=$ GDP growth of ASEAN 4 for time $\mathrm{t}$ and country $\mathrm{i}$

$\mathrm{X}_{\mathrm{it}} \quad=$ Independent Variables (ASEAN 4 consumption growth, investment growth, government expenditure growth, export-import growth and Japan-ChinaKorea GDP growth for time t)

$\mathrm{W}_{\text {it }}$ and $\mathrm{Z}_{\mathrm{it}}=$ Dummy variables which are defined as follows

$\mathrm{W}_{\mathrm{it}} \quad=1$ for country $\mathrm{i}$, where $\mathrm{i}=$ Indonesia, Malaysia, Philippines, Thailand

$=0$ for others

$\mathrm{Z}_{\mathrm{it}} \quad=1$ for Period $\mathrm{t}$ where $\mathrm{t}=1989,1990 \ldots$, 2007

$=0$ for others

The above structural equation is actually a simultaneous equation in which employs causality relationship. To see the simultaneity, the above model can be decomposed into four parts:

$$
\begin{aligned}
& \mathrm{Y}_{\mathrm{t}}=\beta_{1}+\beta_{2} \mathrm{C}_{\mathrm{t}}+\beta_{3} \mathrm{I}_{\mathrm{t}}+\beta_{4} \mathrm{G}_{\mathrm{t}}+\beta_{5} \mathrm{X}_{\mathrm{t}}+ \\
& \beta_{6} \mathrm{JGDP}+\beta_{7} \mathrm{CGDP}_{\mathrm{t}}+\beta_{8} \mathrm{KGDP}_{\mathrm{t}} \\
& \mathrm{C}_{\mathrm{t}}=\beta_{1}+\beta_{2} \mathrm{C}_{\mathrm{t}}+\beta_{3} \mathrm{Y}_{\mathrm{t}} \\
& \mathrm{I}_{\mathrm{t}}=\beta_{1}+\beta_{2} \mathrm{r}_{\mathrm{t}}+\beta_{3} \mathrm{Y}_{\mathrm{t}} \\
& \mathrm{X}_{\mathrm{t}}=\beta_{1}+\beta_{2} \mathrm{EX}_{\mathrm{t}}+\beta_{3} \mathrm{C}_{\mathrm{t}}+\beta_{4} \mathrm{JGDP}_{\mathrm{t}}+ \\
& \beta_{5} \mathrm{CGDP}_{\mathrm{t}}+\beta_{6} \mathrm{KGDP}_{\mathrm{t}}
\end{aligned}
$$

Equation 15 describes the effects of ASEAN 4 consumption $\left(\mathrm{C}_{\mathrm{t}}\right)$, investment $\left(\mathrm{I}_{\mathrm{t}}\right)$, government expenditure $\left(\mathrm{G}_{\mathrm{t}}\right)$, export growth $\left(\mathrm{X}_{\mathrm{t}}\right)$ and the North East Asian GDP growth $\left(\mathrm{JGDP}_{\mathrm{t}}, \mathrm{CGDP}_{\mathrm{t}}, \mathrm{KGDP}_{\mathrm{t}}\right)$ on ASEAN4 GDP growth $\left(\mathrm{Y}_{\mathrm{t}}\right)$. From the model, it is clear that consumption growth, investment growth and export growth have their own determinants that simultaneously form the structural equation. Consumption growth $\left(C_{t}\right)$ is formed by last year's consumption growth $\left(\mathrm{C}_{\mathrm{t}-1}\right)$ and the present GDP growth $\left(\mathrm{Y}_{\mathrm{t}}\right)$, Investment $\left(\mathrm{I}_{\mathrm{t}}\right)$ on the other hand is influenced by the interest rate $\left(r_{t}\right)$ and the GDP growth $\left(\mathrm{C}_{t}\right)$. It is also expected that exchange rate $\left(\mathrm{EX}_{\mathrm{t}}\right)$, consumption growth $\left(\mathrm{C}_{\mathrm{t}}\right)$ and trading partners economic growth $\left(\mathrm{JGDP}_{\mathrm{t}}, \mathrm{CGDP}_{\mathrm{t}}, \mathrm{KGDP}_{\mathrm{t}}\right)$ have some influences on export growth $\left(\mathrm{X}_{\mathrm{t}}\right)$ for ASEAN 4.

From the structural equation, we can divide the variables into two, endogenous and predetermined (exogenous). The first one is treated as stochastic while the latter as non stochastic. To see which simultaneous model that can satisfies the need, we have to address the identification process. If $\mathrm{K}$ is the number of exogenous variables within the model, $\mathrm{k}$ is the number of exogenous variables within the equation and $\mathrm{M}$ is the number of endogenous variable within the model, so the criteria to state whether an equation is unidentified, just identified, or over identified are describe as follows:

If $\mathrm{K}-\mathrm{k}<\mathrm{M}-1$, so the equation is unidentified If $\mathrm{K}-\mathrm{k}=\mathrm{M}-1$, so the equation is exactly identified If $\mathrm{K}-\mathrm{k}>\mathrm{M}-1$, so the equation is over identified

Based form the above criteria, Table 2 summarizes the order condition from the system.

Table 2: Order condition

\begin{tabular}{llll}
\hline No & Equation & Criteria & Conclusion \\
\hline 1 & $\mathrm{Y}_{\mathrm{t}}$ & $6>2$ & Over identified \\
2 & $\mathrm{C}_{\mathrm{t}}$ & $9>1$ & Over identified \\
3 & $\mathrm{I}_{\mathrm{t}}$ & $9>1$ & Over identified \\
4 & $\mathrm{X}_{\mathrm{t}}$ & $6>1$ & Over identified \\
\hline
\end{tabular}


For the case of over identified, we might want to employ two Stage Least Squares (2SLS) approach as an elegant way to deal with such problem. 2SLS regression analysis, as suggested by Angrist and Imbens, (1995). Below is the detailed procedure of 2SLS.

In stage one, least square regression on the reduced form equation has to take place by which it can yields $\mathrm{C}_{\mathrm{t}-1}, \mathrm{Y}_{\mathrm{t}-1}, \mathrm{r}_{\mathrm{t}}, \mathrm{G}_{\mathrm{t}}, \mathrm{EX}_{\mathrm{t}}, \mathrm{JGDP}_{\mathrm{t}}, \mathrm{CGDP}_{\mathrm{t}}, \mathrm{KGDP}_{\mathrm{t}}$ as the instrumental variables, therefore all equations from 15 up to 18 have to be transformed into reduced form equation as the followings:

$$
\begin{aligned}
& \mathrm{Y}_{\mathrm{t}}=\prod_{1}+\prod_{2} \mathrm{C}_{\mathrm{t}}+\prod_{3} \mathrm{Y}_{\mathrm{t}-1}+\prod_{4} \mathrm{r}_{\mathrm{t}}+\prod_{5} \mathrm{G}_{\mathrm{t}}+ \\
& \prod_{6} \mathrm{EX}_{\mathrm{t}}+\prod_{7} \mathrm{JGDP}_{\mathrm{t}}+\prod_{8} \mathrm{CGDP}_{\mathrm{t}}+\prod_{9} \mathrm{KGDP}_{\mathrm{t}} \\
& \mathrm{C}_{\mathrm{t}}=\prod_{10}+\prod_{11} \mathrm{C}_{\mathrm{t}}+\prod_{12} \mathrm{Y}_{\mathrm{t}-1}+\prod_{13} \mathrm{r}_{\mathrm{t}}+\prod_{14} \mathrm{G}_{\mathrm{t}}+ \\
& \prod_{15} \mathrm{EX}_{\mathrm{t}}+\prod_{16} \mathrm{JGDP}_{\mathrm{t}}+\prod_{17} \mathrm{CGDP}_{\mathrm{t}}+\prod_{18} \mathrm{KGDP}_{\mathrm{t}} \\
& \mathrm{I}_{\mathrm{t}}=\prod_{19}+\prod_{20} \mathrm{C}_{\mathrm{t}}+\prod_{21} \mathrm{Y}_{\mathrm{t}-1}+\prod_{22} \mathrm{r}_{\mathrm{t}}+\prod_{23} \mathrm{G}_{\mathrm{t}}+ \\
& \prod_{24} \mathrm{EX}_{\mathrm{t}}+\prod_{25} \mathrm{JGDP}_{\mathrm{t}}+\prod_{26} \mathrm{CGDP}_{\mathrm{t}}+\prod_{27} \mathrm{KGDP}_{\mathrm{t}} \\
& \mathrm{X}_{\mathrm{t}}=\prod_{28}+\prod_{29} \mathrm{C}_{\mathrm{t}}+\prod_{30} \mathrm{Y}_{\mathrm{t}-1}+\prod_{31} \mathrm{r}_{\mathrm{t}}+\prod_{32} \mathrm{G}_{\mathrm{t}}+ \\
& \prod_{33} \mathrm{EX}_{\mathrm{t}}+\prod_{34} \mathrm{JGDP}_{\mathrm{t}}+\prod_{35} \mathrm{CGDP}_{\mathrm{t}}+\prod_{36} \mathrm{KGDP}_{\mathrm{t}}
\end{aligned}
$$

$$
\text { Note }: \prod \text { is } \frac{\beta}{1-\beta}
$$

From stage one we get $\hat{\mathrm{y}}_{\mathrm{T}}, \hat{\mathrm{C}}_{\mathrm{t}}, \hat{\mathrm{I}}_{\mathrm{t}}, \hat{\mathrm{X}}_{\mathrm{t}}$ as the fitted values with which we can run for the second stage. In stage two, these fitted values are then plugged in to the main equation. The last step is to run least squares on each of the above equations to get 2SLS estimation as described in Table 6.

The future trend of East Asian Regionalism (EAR): The next task is to shape the future of EAR, but then will the future exist? In this study, we measure the trend toward openness Vis a Vis regionalism by using ECM for the RPL index in North East Asia (CJK). Since we include two sub regions, the best way to measure it is by using test of convergence of the term of trade for CJK and ASEAN4. The notion of convergence implies that differences between the series must follow a stationary process (Bernard and Durlauf, 1995; Oxley and Greasley, 1995) Thus, stochastic convergence implies that the sub regions will form the so called EAR. But knowing the future is not enough, we still need to find out the clear path to reach the future. The following serves to give the answer.

Factors contributing to EAR: Feng and Genna (2003) argued that homogeneity of domestic institutions is needed to go hand in hand with the regional integration process. Moreover, they pointed out inflation, taxation and government regulation as representing factors for the economic institutions. Another variable that might enhance integration is population as already identified by Tamura (1995). He argued that large population is a catalyst for integration due to economic agglomeration. Scholars like Milner and Kubota (2005) even pointed out democracy as an important factor that could foster regionalism. Their empirical work on the developing countries from 1970-1999 showed that regime change toward democracy was associated with trade liberalization and regionalization.

Given those works, this study tries to combine the variables into one complete model that can determine the formation of EAR.

The formula as follows:

$$
\begin{aligned}
& \text { Open }_{\mathrm{it}}=\alpha+\beta \mathrm{X}_{\mathrm{it}}+\gamma_{1} \mathrm{~W}_{1 \mathrm{t}}+\gamma_{2} \mathrm{~W}_{2 \mathrm{t}}+\gamma_{3} \mathrm{~W}_{3 \mathrm{t}}+\ldots+ \\
& \gamma_{\mathrm{N}} \mathrm{W}_{\mathrm{N}}+\delta_{1} \mathrm{Z}_{\mathrm{i} 1}+\delta_{2} \mathrm{Z}_{\mathrm{i} 2}+\delta_{3} \mathrm{Z}_{\mathrm{i} 3}+\ldots .+\delta_{\mathrm{t}} \mathrm{Z}_{\mathrm{iT}}+\mathrm{E}_{\mathrm{it}}
\end{aligned}
$$

Where:

$$
\begin{array}{rl}
\text { Open }_{\mathrm{it}}= & \text { Regionalism for time } \mathrm{t} \text { and country } \mathrm{i} \\
\mathrm{X}_{\mathrm{it}} & \text { Independent Variables (ASEAN4 }+ \\
& \text { CJK's rail ways, tax, democracy, } \\
& \text { governance, industry, gross school } \\
& \text { enrolment rate, inflation and population) } \\
& \text { dummy variables which are defined as } \\
\mathrm{W}_{\mathrm{it}} \text { and } \mathrm{Z}_{\mathrm{it}}= & \text { follows: } \\
\mathrm{W}_{\mathrm{it}} & 1 \text { for country } \mathrm{i} \text {, where } \mathrm{i}=\text { Indonesia, } \\
& \text { Malaysia, Philippines, Thailand China, } \\
& \text { Japan, Korea } \\
= & 0 \text { for others } \\
= & 1 \text { for Period } \mathrm{t} \text { where } \mathrm{t}=1998,2000 \ldots, \\
& 2007 \\
= & 0 \text { for others }
\end{array}
$$

The study employs fixed effect model to estimate the variables. The variables are taken from the World Bank's World Development Indicators (WDI). The followings are the explanations for the variables used: (i) the study use the proxy of trade openness (net export per GDP) for regionalism. The variable of openness is used to represent regionalism since regionalism creates openness to some sectors of economy. Openness here functions as dependent variable that is determined by some independent variables. (ii) Railways as goods transported (million ton-km) is used to explain physical infrastructure readiness. Pairing up with this variable is the gross school enrolment rate which serves as the basic for human capital infrastructure. Sound infrastructure (both physical and human) will provide steadiness and assuredness in making investment among members. In other words, good infrastructure 
Am. J. of Economics and Business Administration 3 (2): 247-258, 2011

will only lead to a sustainable intra trade and investment that serve as the basis of EAR. (iii) To measure democracy, the indices produced by Freedom House (2000) hat is the index of democracy called POLITY. Democratization is expected to open up new avenues of support for freer trade vis-à-vis regionalism. (iv) Moving to the next variable is the taxation policy, the higher the rate the more it will diminish the prospects of EAR. (v) Other variable that also matters is governance which is measured by the six governance indicators estimated by Kaufmann et al. (2003). These indices describe various aspects of the governance structures of a broad cross section of countries, including measures of Voice and Accountability, Political stability, Government Effectiveness, Regulatory Quality, Rule of Law and Control of Corruption. In general, the Governance index provides explanatory power to explain the capability and quality of governance from each member country. The better indicator a country has the more it has the chance to capitalize regionalism. (vi) Macroeconomic variable which is represented by inflation creates ambiguous expectation. High inflation might deter the formation of EAR since the very beginning but some scholars prove the other way around. One of argument that supporting the latter proposition is given by Cohen (1997) who argued that the inflationary policy (high inflation) resulting from the government action will tend to raise the obstacle to private investors which in turn demand for greater integration. The loss of discretion in the fiscal and monetary policy will then reduced the risk of uncertainty. (vii) Large market together with the ongoing industrialization process sums up the last aspects of EAR formation. The sheer size of the East Asian population creates not only the potential demand for the goods traded in the region but also the supply of labor force and the low absolute level of wages. In other words, Lewis's unlimited supply of labor will persist longer in East Asia. The process will lead to an upward trend towards industrialization (value added as percentage from GDP) in the region.

The trend is very important since homogeneity in industrialization among countries in the region will smooth the progress of EAR.

\section{RESULTS AND DISCUSSION}

The long run equilibrium: From Table 3 we can see that, GDP and export relationship in the CJK yields stability in the long run. It is proven by the stationarity of the error term in each of the cases. The cointegration test that proves long run equilibrium describes that the model is not spurious. Export is proven to be the engine
Table 3: Cointegration parameters

\begin{tabular}{|c|c|c|c|}
\hline $\begin{array}{l}\text { Dependent } \\
\text { variables }\end{array}$ & & & \\
\hline $\begin{array}{l}\text { Independent } \\
\text { variables }\end{array}$ & $\begin{array}{l}\text { GDP } \\
\text { (Japan) }\end{array}$ & $\begin{array}{l}\text { GDP } \\
\text { (China) }\end{array}$ & $\begin{array}{l}\text { GDP } \\
\text { (Korea) }\end{array}$ \\
\hline Export to Japan & na & Stationer & Stationer \\
\hline Export to China & Stationer & na & Stationer \\
\hline Export to Korea & Stationer & Stationer & na \\
\hline
\end{tabular}

of economic advancement in these countries. It approves some previous research as the likes of Dorasami (1996), Ekanayake (1999) and Fosu and Magnus (2006) of export and economic growth relationship.

The short run Equilibrium: Equation 8 has shown that the long run relation between Export and GDP in Japan, China and Korea would be balanced by the previous error. Table 4 provides the short run output for CJK.

China: The residuals for the relationship between China's GDP with China's Export to Japan and Korea are significant. These suggest that there is an equilibrium error in the short run. The negative signs put the Export for a constant rise to reach the long run equilibrium. In China's case, the adjustment rate or the phase of acceleration for the long run equilibrium is very fast. It can be seen through the absolute value of the equilibrium error coefficients which are 1.09 and 1.33 for China's relationship to Korea and Japan respectively.

Japan: In the short run, there is an equilibrium error for Japan's Export to China with its relation to Japan's GDP. The coefficient of residual gives negative sign $(-0.18)$, which means that Japan's Export to China is below the long run equilibrium. This will only lead to a rise of export for the following periods. But it is important to note that the absolute value of the coefficient (adjustment rate) is very small (0.18). This suggests that Japan's Export to China is moving in a slow phase to reach the long run equilibrium.

As for the relationship between Japan and Korea, the equilibrium error of the export trend is not significant. These suggest that Japan's GDP is adjusting to the change in Japan's export to Korea in the same period of time. In other words, Japan and Korea relationship in terms of export has already reached steady state level.

Korea: Korea's case is somewhat similar to China. The residuals for the relationship between Korea's GDP with Korea's Export to Japan and China are significant. 
It yields similar explanation with China's case. However, the adjustment rate for the case of Korea is slower than China's but it is still faster than Japan's. It gives the absolute value of 0.23 and 0.48 for Korea's trade relationship to Japan and China respectively.

Interim conclusion: From the ECM, we can conclude that North East Asian region is not moving at the same phase to reach the long run equilibrium, which in this case Japan is the slowest one. The insignificant value of acceleration rate for the case of Japan trade relationship with Korea is also important point to note since it can be interpreted as an exhausted Korean market for Japanese products (steady state condition). These facts are very crucial since it diminishes Japan's role as the sole leader in the north East Asia. Although whoever the leader is not to important, but the stalled effect of a country's economic growth in these region will only serve as stumbling blocks in creating East Asian welfare. The rising growth of China and Korea will soon meet its end mimicking the pattern of Japan if no serious action is sited. Therefore, In order to strengthen regional welfare and accelerate the phase of adjusting, economic integration must take place.

Trade openness: From table 5 we can see that generally trade openness is affecting a country's GDP in a positive way. But in the short run, trade openness in the CJK is still below the equilibrium. This suggests that trade openness is still finding its form in this area. Although we might not see regionalism which liberalize trade in the short run, but the trend towards openness in trade Vis a Vis regionalism is progressing in a respectful manner. We can see this through the adjustment rate for the long run equilibrium (the coefficients of residuals) that yields an average of 1.1; consequently we might see regionalism in North East Asia happen in the future.
Spill-Over Effect: From table 6 we can conclude that the North East Asian (Japan, Korea and China) economic growth boost the ASEAN4 economic growth, it confirms the proposition of this study. Investment flows, in the form of FDI, has also operated as a dominant integrating power in East Asia as whole. Although we cannot find legitimate determinant for FDI in the output, but it is clear that FDI is trade related in nature. With its essentially open and outward-looking economies, the region is highly dependent on foreign investment for its economic growth. But still, the boosting power is not as much as in the spillover effect from the giant countries of Japan, Korea and China. Japan, in terms of GDP growth, has the biggest influence towards ASEAN4 followed by China and Korea at the second and third place. This fact is described by the coefficient parameter that gives the value of $0.546,0.311$ and 0.250 for Japan, China and Korea respectively.

The ranking of influence is presumably caused by the number FDI inflows to ASEAN from these countries as described in Table 7. The only bias is on China and Korea, even though the cumulative FDI from Korea to ASEAN4 was bigger than China's, but it does not seem to be reflected on the ranking of influence. As for this, it is assumed that the high economic growth rate of China had been the major contributing factor (Urata and Kiyota, 2003) that overtook the influence of Korea's cumulative FDI flow to ASEAN4. However, such factor is not enough to surpass (From the ECM simulation as confirmed earlier, we found that China has taken over Japan's role in East Asia. But this is true if we address the long run effect. This section only measures the present condition in the absence of the intertemporal problem.) Japan's influence to ASEAN4's economic growth since Japan's FDI contribution to ASEAN4 outweighed China's by more than one hundred folds.

Table 4: Equilibrium errors

\begin{tabular}{|c|c|c|c|}
\hline \multicolumn{4}{|l|}{$\begin{array}{l}\text { Dependent variables } \\
\text { Independent variables }\end{array}$} \\
\hline Equilibrium error for export to Japan & na & $-1.09 * * *$ & $-0.23 *$ \\
\hline Equilibrium error for export to China & $-0.18 * * *$ & na & $-0.48 * * *$ \\
\hline Equilibrium error for export to Korea & 0.017773 & $-1.33 * * *$ & na \\
\hline \multicolumn{4}{|c|}{ Note: Statistical significance is indicated by $*(10 \%), * *(5 \%)$ and $* * *(1 \%)$} \\
\hline \multicolumn{4}{|l|}{ Table 5 Cointegration parameters } \\
\hline \multicolumn{4}{|l|}{ Dependent variables } \\
\hline Independent variables & GDP (Japan) & GDP (China) & GDP (Korea) \\
\hline Equilibrium error for openness to Japan & na & $-1.23 * * *$ & $-1.31 * * *$ \\
\hline Equilibrium error for openness to China & $-1.15 * * *$ & na & $-0.97 * * *$ \\
\hline Equilibrium error for openness to Korea & $-0.72 * *$ & $-1.24 * * *$ & na \\
\hline
\end{tabular}

Note: Statistical significance is indicated by $*(10 \%), * *(5 \%)$ and $* * *(1 \%)$ 
Am. J. of Economics and Business Administration 3 (2): 247-258, 2011

Table 6: Two stage least squares regression output

\begin{tabular}{|c|c|c|c|c|}
\hline $\begin{array}{l}\text { Dependent Variables } \\
\text { Independent Variables }\end{array}$ & $\mathrm{Y}$ & \multicolumn{3}{|c|}{ Dependent Variables } \\
\hline$\overline{\mathrm{Y}}$ & na & $0.776 * * *$ & -0.087 & \\
\hline $\mathrm{C}$ & $0.470 * * *$ & na & na & $-0.64 * *$ \\
\hline I & 0.025 & na & na & na \\
\hline $\mathrm{X}$ & $0.072 *$ & na & na & na \\
\hline \multicolumn{5}{|l|}{ Instrumental variables } \\
\hline Y (Japan) & $0.546 * *$ & na & na & $2.949^{* * *}$ \\
\hline Y (China) & $0.311 * *$ & na & na & $1.112 * * *$ \\
\hline Y (Korea) & $0.250 * *$ & na & na & -3.760 \\
\hline$C(-1)$ & na & 0.01 & na & na \\
\hline $\mathrm{r}$ & na & na & 0.137 & na \\
\hline $\mathrm{Y}(-1)$ & na & na & na & na \\
\hline EX & & na & na & 0 \\
\hline $\mathrm{G}$ & $0.122 * *$ & na & na & na \\
\hline
\end{tabular}

Table 7: FDI flows to ASEAN 4 (US\$ million)

\begin{tabular}{|c|c|c|c|c|c|}
\hline Host country & Indonesia & Thailand & Malaysia & Phillipines & $\begin{array}{l}\text { Total Cummulative } \\
1995-2003\end{array}$ \\
\hline Source country & & & & & \\
\hline Japan & 288.06 & $8,096.02$ & $4,761.11$ & $3,055.68$ & 16200.87 \\
\hline Korea & 331.88 & 235.58 & 98.51 & 238.13 & 904.10 \\
\hline China & -36.78 & 50.16 & 120.72 & 4.07 & 138.17 \\
\hline
\end{tabular}

Source: ASEAN secretariat

The story goes hand in hand with the flying-geese hypothesis that was developed by Japanese economist, Akamatsu (1935). his model has been frequently proposed to examine the patterns and characteristics of East Asian economic integration. "The premise of the flying-geese pattern suggests that a group of nations in this region are flying together in layers with Japan at the front layer. The layers signify the different stages of economic development achieved in various countries" (Xing, 2007). In the flying-geese model of regional economic development, Japan as the leading goose leads the second-tier geese (China, Korea) which, in their turn, are followed by the third-tier geese (ASEAN4).

Another important thing to note is the low significant value of exports within ASEAN4 in terms of creating GDP growth. These are intriguing facts since export is considered as the main determinant of GDP growth. It is suspected that the effect of rivalry between ASEAN4 members and China is the main factor which creates insignificant value. This factor is supported by Holst and Weiss (2004) hat pointed out China's emergence for creating short and medium term direct and indirect competition between ASEAN and China. They argued that ASEAN and China are experiencing intensified export competition in prominent third markets. This can lead to painful domestic structural adjustments within the ASEAN in the short run. Then again the mind set in viewing the economic opportunity or threat depends on whether China's economy is perceived as complementary or competitive vis-à-vis individual ASEAN economies and on whether the latter economies are able to exploit their complementary opportunities and overcome the competitive threats.
Chia (2006) argued that "the differences in resource and factor endowments, production structures and productivities lead to a complementary relationship, whereas similarities in these areas lead to a competitive relationship".

The trend of convergence: Following Bernard and Durlauf (1995) stochastic convergence occurs if the differential log trade system, yt, follows a stationary process, where $y_{t}=$ ASEAN4tot $_{t}-$ CJKtot $_{t}$, where ASEAN4tot $_{t}$ is the logarithm term of trade of ASEAN4and CJKtot $_{t}$ is logarithm term of trade of CJK and both series are in the first difference (I(1)). Stochastic convergence is tested by using the conventional Augmented Dickey-Fuller (ADF) regression which shows a significance result in proving stationarity for $\mathrm{y}_{\mathrm{t}}$ (Table 8). This indicates long-run convergence between the two trading systems.

A major drawback of the standard ADF unit root test procedure is that the power of the test is quite low. To overcome this problem, the study utilizes cointegration test as suggested by Wignaraja et al. (2007). The following is the Engle Granger Cointegration:

$\mathrm{U}_{\mathrm{t}}=$ ASEANtot $_{\mathrm{t}}-\beta_{0}-\beta_{1} \mathrm{CJKtot}_{\mathrm{t}}$

The residual $\left(\mathrm{U}_{\mathrm{t}}\right)$ gives stationary result (Table 9) which means that the two regions have long run relationship (convergence). It is worth to say that with the test of convergence, EAR will be there to stay in the long run. The robust finding surely creates optimistic view for EAR. 
Am. J. of Economics and Business Administration 3 (2): 247-258, 2011

Table 8: ADF test for term of trade

\begin{tabular}{lllr}
\hline ADF test statistic & -3.519465 & 1\% Critical Value* & -3.7204 \\
& 5\% Critical Value & -2.9850 \\
& $10 \%$ Critical Value & -2.6318 \\
\hline *MacKinnon critical values for rejection of hypothesis of a unit root \\
\multicolumn{4}{c}{} \\
\multicolumn{4}{l}{ Table 9: ADF test for co integration residual } \\
\hline ADF test statistic & -5.623714 & 1\% Critical value* & -3.7204 \\
& $5 \%$ Critical value & -2.9850 \\
& $10 \%$ Critical value & -2.6318 \\
\hline
\end{tabular}

*MacKinnon critical values for rejection of hypothesis of a unit root

Table 10: Factors affecting openness

Dependent variable: OPENNES

\begin{tabular}{lcc}
\hline Independent variable & Coefficient & t-Statistic \\
\hline LOG (RAILWAYS) & 0.115860 & $2.059379^{* *}$ \\
TAX & -0.029831 & $-3.530943^{* * *}$ \\
DEMOCRACY & -0.004282 & $-2.051852^{* *}$ \\
GOVERNANCE & 0.257508 & $3.860438^{* * *}$ \\
INDUSTRY & 0.049930 & $4.861010^{* * *}$ \\
LOG (POPULATION) & 0.863634 & $2.154852^{* *}$ \\
GROSS EDUCATION & 0.011445 & $2.217493^{* *}$ \\
INFLATION & -0.001545 & -0.441719 \\
R-squared & 0.992510 & \\
Adjusted R-squared & 0.989750 & \\
\hline
\end{tabular}

Note: Statistical significance is indicated by $*(10 \%),{ }^{* *}(5 \%)$ and $* * *$ $(1 \%)$

In the long run, regionalism is expected to accommodate welfare for East Asia. Thus, a unified East Asia could accelerate the momentum of overall trade liberalization and boost regional economic growth.

Factors Affecting EAR: Table 10 shows us that Economic and political factors such as Infrastructure (railways and gross education), governance, taxation policy, industrialization and Democracy have significant effect towards Regionalism (Openness) in East Asia while Inflation gives insignificant role.

The signs of coefficient for railways, gross education, governance and industrialization are positive which mean the bigger the variable the more they create Openness. The negative sign of the coefficient for tax describes the opposite relation between corporate tax rate and the future prospect of EAR, the higher the rate the more it will the deteriorate the EAR. The negative sign of democracy is against expectation but it is still rational since democracy is still finding its form in East Asia. We have to define what democracy really means in order to make it works. The insignificant role of inflation for EAR is expected due to the ambiguity given.

\section{CONCLUSION}

We have made an interim conclusion that export leads the overall growth in North East Asia. However, it is important to note that Japan's phase of adjustment towards long run equilibrium is quite slow compared to the likes of Korea and China. This only yields as a stumbling block in forming regionalism in East Asia. The hard task is about making these countries move together in the same phase, which is why regionalism has to take place.

Since regionalism is an abstract term, the use of RPL index is essential. RPL index is a proxy of outward orientation of a country or in other words it is a representation of regionalism. Regionalism in this case goes hand in hand with openness in which it creates trade arrangements that liberalize some sectors in the economy. The ECM simulation gives a clear picture of the current form of openness which is below the equilibrium. It suggests that the trend towards regionalism is still far behind. It somewhat confirms the ineffectiveness of current triangular trade in North East Asia. It is expected that regionalism can eliminates such bias in trade.

Moreover, since North East Asian countries has a big scale of economy, its economic development will substantially affect the neighboring countries in East Asia specifically ASEAN4. It is demonstrated by the large share of China-Japan-Korea growth that affects ASEAN4's GDP.

In the short run, there is a rivalry competition between China and ASEAN. However, in the long run regionalism is expected to accommodate export growth for East Asia as whole. In a sense of creating integration in East Asia, there is a need to set up more formal institutional mechanisms for trade. It is rational for such mutually dependent countries in the region to institutionalize de facto integration through the establishment of regional arrangements (Kawai, 2005). The growing significance of China, Japan and Korea market for ASEAN4 will then serve as the basis for a single East Asian Wide FTA. The next task is to shape the future of EAR, but then will the future exist? Using the test of convergence, it is found that EAR will be there to stay. The robust finding surely creates optimistic view for EAR. But knowing the future is not enough, we still need to find out the clear path to reach the future. What are the paths then? From a static panel data simulation it is found that sound physical infrastructure, good governance, inflation, competitive taxation policy, sizeable market and the trend towards industrialization are the main factors that serve as building blocks for EAR.

To wrap up, EAR will enable the region to cope with the future challenges of globalization and remain internationally competitive. An integrated East Asia 
would lead to the advancement in economies of scale, fuller development of production networks. Moreover, Chia (2006) stated that EAR could help the less developed East Asian economies which would otherwise become marginalized as they lack the attraction of sizeable market and lack negotiating resources.

\section{REFERENCE}

Akamatsu, K., 1935. Wagakuni yomo kogyohin no susei [trend of Japanese trade in woolen goods], Shogyo Keizai Ronso. J. Nagoya Higher Comm. School,13: 129-212.

Angrist, J. D and G.W. Imbens, 1995. Two-stage least squares estimation of average causal effects in models with variable treatment intensity. J. Am. Statist. Assoc., 90: 431-442. DOI: $10.2307 / 2291054$

Bernard, A. B. and S.N. Durlauf, 1995. Convergence in international output. J. Applied Econ., 10: 97-108. DOI: 10.1002/JAE.3950100202

Chan, S. and C.C. Kuo, 2005. Trilateral trade relations among China, Japan and South Korea: Challenges and prospects of regional economic integration. J. East Asia, 22: 33-50. DOI: 10.1007/S12140-0050019-1

Charles, H. and H.H. Lee, 2002. New Regionalism in East Asia: How Does It Relate to the East Asian Economic Development Model. School of Economics, University of Wollongong, NSW, Australia.

http://econpapers.repec.org/paper/uowdepec1/wp0 2-10.htm

Chia, S.Y., 2006. ASEAN-China Economic Competition and Free Trade Area. Asian Econ. Papers, 4: 109-147.

Cohen, B.J., 1997. The Political Economy of Currency Regions. In: The Political Economy of Regionalism, E.D. Mansfield H.V. Milner, and (Eds.). Columbia University Press, New York, pp: 50-75.

Dollar, D., 1992. Outward-oriented developing economies really do grow more rapidly: Evidence From 95 LDCs, 1976-1985. J. Econ. Develop. Cultural Change, 40: 523-544.

Dorasami, A., 1996. Export growth and economic growth: A reexamination of some time-series evidence of the Malaysian experience. J. Dev. Areas, 30: 223-230.

Dritsakis, N. and K. Gialetaki, 2005. Macro-economic Variables Analysis in Ukraine: An empirical approach with cointegration method. Am. J.
Applied Sci., 2: 836-842. $\quad$ DOI: 10.3844/AJASSP.2005.836.842

Ekanayake, E.M., 1999. Exports and economic growth in Asian developing countries: Cointegration and error-correction models. J. Econ. Dev., 24: 43-56.

Engle, R.F. and C.W.J. Granger, 1987.Co-integration and error correction: Representation, estimation and testing. Econometrica, 55: 251-76. DOI: $10.2307 / 1913236$

Feng, Y. and G. Genna, 2003. Regional integration and domestic institutional homogeneity: A comparative analysis of regional integration in the Americas, Pacific Asia and Western Europe. Rev. Int. Polit. Econ., 10 : 223-230. DOI: $10.1080 / 0969229032000063234$

Fosu, O.A.E. and F.J. Magnus, 2006. bounds testing approach to cointegration: An examination of foreign direct investment trade and growth relationships. Am. J. Applied Sci., 3: 2079-2085. DOI: 10.3844/AJASSP.2006.2079.2085

Habibi, F. and K.A. Rahim, 2009. A bound test approach to cointegration of tourism demand. Am. J. Applied Sci., 6: 1924-1931. DOI: 10.3844/AJASSP.2009.1924.1931

Holst, D.R. and J. Weiss, 2004. ASEAN and China: export rivals or partners in regional growth? The World Econ., 27: 1255-1274.

Kaufmann, D., A. Kraay and M. Mastruzzi, 2003. Governance Matters III: Governance Indicators for 1996-2002. 1st Edn., World Bank, World Bank Institute, Global Governance Department, and, Development Research Group, Macroeconomics and Growth, USA., pp: 115.

Kawai, M., 2005. East Asian economic regionalism: progress and challenges. J. Asian Econ., 16: 29-55. DOI: 10.1016/J.ASIECO.2005.01.001

Khosravi, A. and M.S. Karimi, 2010. To investigation the relationship between monetary, fiscal policy and economic growth in Iran: Autoregressive distributed lag approach to cointegration. Am. J. Applied Sci., 7: 415-419. DOI: 10.3844/ajassp.2010.415.419

Masahiro, K. and G. Wignaraja, 2007. Regionalism as an Engine of Multilateralism: A Case for a Single East Asian FTA. ADB Working Paper series on Regional Economic Integration no.14. http://www.aric.adb.org/pdf/workingpaper/WP14_ East_Asian_FTA.pdf

Milner, H.V. and K. Kubota, 2005. Why the move to free trade? Democracy and trade policy in the developing countries. Int. Organization, 59: 107-143. DOI: $10.1017 / \mathrm{S} 002081830505006 \mathrm{X}$

Nachrowi, D., 2006. Ekonometrika U/analisis Ekonomi and Keuangan. 1st Edn., Gramedia, Indonesia, ISBN: 9792452060 , pp: 456. 
Oxley, L. and D. Greasley, 1995. A time-series perspective on convergence: Australia, UK and USA since 1870. Econ. Rec., 71: 259-270. DOI: 10.1111/J.1475-4932.1995.TB01893.X

Summers, R. and A. Heston, 1988. A new set of international comparisons of real product and price levels: Estimates for 130 countries, 1950-1985. Rev. Income Wealth, 34: 1-25. DOI: 10.1111/J.1475-4991.1988.TB00558.X

Tamura, R., 1995. Regional economies and market integration. J. Econ. Dynam. Cont., 20: 825-845. DOI: $10.1016 / 0165-1889(95) 00878-0$

Toosi, M., R. Moghaddasi, S. Yazdani and M. Ahmadian, 2009. Regionalism and Its effects on iranian agricultural exports: The case of economic cooperation organization. Am. J. Applied Sci., 6: 1380-1384. DOI: 10.3844/ajassp.2009.1380.1384
Urata, S. and K. Kiyota, 2003. The Impacts of an East Asia FTA on Foreign Trade in East Asia. 1st Edn., National Bureau of Economic Research, Cambridge, pp: 18.

Xing, L., 2007. East Asian Regional Integration: From Japan-led "Flying-geese" to China-centered Bamboo Capitalism. 1st Edn., CCIS, Aalborg, pp: 23.

Yorizumi, 2008. Economic Partnership Agreement (EPA) of Japan and Economic Integration in Northeast Asia. Academic presentation, Graduate School of Media and Governance, Keio University. http://fekon.unand.ac.id/icbe/images/Paper/Region alism\%20in\%20East\%20Asia_\%20The\%20Role\% 20 of $\% 20$ North $\% 20$ East $\% 20$ Asian $\% 20$ Nations.pdf 